\title{
An overview of the Feed-in Tariff policy development in Indonesia
}

\author{
Himsar Ambarita \\ Sustainable Energy Research Center \\ Faculty of Engineering, University of Sumatera Utara \\ Medan 20155, Indonesia \\ Email: himsar@usu.ac.id
}

\author{
Hideki Kawai \\ Department of Mechanical Engineering \\ Muroran Institute of Technology \\ Muroran 8585, Hokkaido, Japan
}

\begin{abstract}
Indonesia is blessed with abundant renewable energy resources that can be used to produce electricity for national grid. However, only a small amount of the renewable energy resources, less than $10 \%$, has been utilized to produce electricity. The energy share is still dominated by fossil fuel which results in greenhouse gas emission. In order to increase the energy share and reduce greenhouse gas emission, the Government of Indonesia (GoI) has released several financial mechanisms in supporting the growth of the Independent Power Producers (IPP) to produce electricity from renewable energy resources. One of the potential mechanisms is the Feed-in tariff (FIT) policy. The FIT allows the PLN (State Electricity Company) to buy the electricity produced by the IPPs from renewable energy resource with a higher price and sell it to the costumer below the buying price. In this work, the history of the FIT in Indonesia is overviewed. The results show that FIT has changed several times to meet the need of IPP. However, the FIT has no significant effect yet to the growth of the IPP. Thus, other supporting financial mechanisms must be provided by the GoI.
\end{abstract}

\section{Keywords-Feed-in tariff; renewable energy; energy price}

\section{INTRODUCTION}

Indonesia is a country that consist of more than 17,000 islands lying between two continents, Asia and Australia, also between and between the Indian Ocean and Pacific Ocean. The population is 161 million people. This makes Indonesia is the fourth country with the highest population in the world, after China, India, and United States. One of the main challenges of Indonesia development is to provide green energy for sustainable development. Indonesia has a strong commitment on increasing renewable energy utilization. This is due to reduction of Greenhouse gas (GHG) emission and to increase energy mix. As a note, Indonesia is known as has released a new target on GHG emission reduction. The target says that Indonesian will reduce its emission $29 \%$ below business-asusual (BAU) and it can be up to $41 \%$ by using international aids by the year 2030. Indonesia is blessed with abundant Renewable Energy resources. However, only very limited number of the potency has been explored to produce useful energy. In order to enhance the utilization of the renewable energy resources, many supporting policies can be implemented. One of the most implemented policy is Feed-in tariff (FiT).
FiT is an energy supply policy focused on supporting the development of renewable energy (RE) independent power producer (IPP) by offering long-term purchase agreements for sale of the produced renewable energy electricity. The power purchase agreements are typically offered within contracts ranging from 10-25 years. Many countries have implemented FiT in order to support the development of RE IPP. Supriyasilp et al. [1] explored the challenge of incentive for small hydropower commercial investment in Thailand. In order to improve the renewable energy development, Thailand implemented a premium-price Feed-in Tariff (FiT) in 2006. However, this system has failed to motivate the investors. Later, Thailand government replace the program into a fixed-price FiT program since 2014. Thus the, the effectiveness of the latest FiT was investigated. The study recommended a supporting program to the FiT such as promoting social cost and social benefits. Garcia-Alvarez and Mariz-Perez [2] reported the analysis of the success of FiT for renewable promotion mechanism in the Europe. The study performed in Germany and Spain which are known as countries with highest installed capacity and production of renewable energy. The results show that the development of the renewable energy entails an element of environmental protection, a considerable increase of employment, positive contribution to GDP, the development research, investment and innovation with the consequence creation of an important industrial fabrication sector. It was concluded that the establishment of FiT system allows for the development of those development technologies. Tongsopit and Greacen [3] presented an overview of FiT in Thailand which is known as the first Asian countries with a comprehensive FiT program. Chua et al. [4] presented the FiT outlook in Malaysia, which is in the process of being enacted through a RE policy by the government. The results showed that the successful utilization of RE source in electricity generation and the FiT implementation globally are positive indicators to implement FiT in Malaysia. Koo [5] examined the impacts of FiT and the clean development mechanism (CDM) on Korea's renewable energy projects through comparative investment analysis. The FiTs and CDMs were compared using financial indicators to measure their relative contributions on profitability. The results revealed that CDM is partial towards large scale projects with high emission reductions. Moreover, conflicts with FiT schemes can deter small scale, capital intensive projects from pursuing registration. Poruschi et al. [6] reported a review study on FiT in Australia. The purposes are 
to synthesis a set of data on FiT policy which can be used to inform future Australia-wide policy analysis, to understand the coevolution of policies to subsidise solar panel installation; installation cost; and installation number; and to employ the set data on FiT policy to examine whether FiT policy corresponds with unintended adverse energy justice outcomes.

Several studies on a particular renewable energy FiT are also found in literature. Lim et al. [7] reported feasibility study of marine renewable energy to the FIT system in Malaysia. The objective was to suggest appropriate FiT rates of marine renewable energy (MRE) based on Net Present Value (NPV) approach. The results showed that reasonable FiT rates of MRE in Malaysia should be in the range of $0.06-0.6$ Euro/kWh depending on the type of MRE technology used. Pablo-Romero et al. [8] reported the analysis of the measures implemented in the EU-28 to promote biogas, relating them to the country targets established in their National Renewable Energy Action Plans. Umar et al. [9] investigated generating renewable energy from oil palm biomass in Malaysia in the FiT policy framework. The above studies show that development of FiT in many countries are specific and different in a particular country. The experience from a country can provide sufficient information to develop a suitable FiT for another country.

The Government of Indonesia also implemented FiT to enhance RE IPP development. The first FiT in Indonesia has been implemented since 2009 . However only limited study on the Indonesia FiT is found in literature. Bakhtyar et al. [10] investigated the potential and challenges in the implementing feed-in tariff policy in Indonesia and the Philippines. The results showed that the role of the government in providing support to investors is not clear in both countries. In addition, inflation rates have not been calculated. However, FiT has both countries by preventing degression during the primary years. In this paper the development of FiT in Indonesia will be overviewed. The objective is to provide the history of Indonesian FiT in every renewable technology. The results are expected to supply the necessary information for development of optimum FiT in Indonesia.

\section{METHODS}

The methodology used in this study consists of literature and document review, interview, and site visit. The literature and documents that are reviewed includes law and regulations related to FiT issued by the Government of Indonesia. The interviews with related stake holders are carried out. The stakeholders include government officers, state electricity company (PLN), local head of regencies, project owner, academicians, consultants, Financial institutions, and social leader and local people close to the power plant projects. Several site visits to the power plant projects are also carried out. The study was performed during 2012 to 2017 .

The results will be presented in two sections. In the first section the potency of renewable energy in Indonesia will be presented. The potency and the explored capacity will be discussed. In the second section the history of FiT in every technology will be overviewed. Based on the discussion several conclusions will be drawn.

\section{RESULTS AND DISCUSSIONS}

\section{A. Renewable Potency in Indonesia}

The potency of Renewable Energy in Indonesia is shown in Table 1. The table shows that the biggest potency of renewable energy in Indonesia is hydropower which includes Mini and Micro hydro. The estimation is $75 \mathrm{GW}$. This potency includes the identified potency of 45,379 MW. The second biggest potency is Ocean Thermal Energy Conversion (OTEC). It is 41,012 MW. The third and the fourth are Biomass and Geothermal renewable energy resources, respectively. This fact reveals that Indonesia is blessed with abundant renewable energy resources. However, only a small portion of this potency has been explored. According to Kuncoro et al. [12], in year 2011 , only $10 \%$ of the total energy in Indonesia produced by hydropower. The explored energy from Biomass and Geothermal are $1618 \mathrm{MW}$ and $1200 \mathrm{MW}$, respectively. The installed capacity of solar and wind power are $13.5 \mathrm{MW}$ and 0.5 MW. There is no power produced from Wave, OTEC and Tidal energy.

TABLE I. RENEWABLE ENERGY IN INDONESIA [11]

\begin{tabular}{|l|l|c|c|}
\hline No & \multicolumn{1}{|c|}{ Resources } & Potency & Note \\
\hline 1 & Geothermal & $29,543.5 \mathrm{MWe}$ & \\
\hline 2 & Hydropower & $75,000 \mathrm{MW}$ & $\begin{array}{c}\text { Identified } \\
45,379 \mathrm{MW}\end{array}$ \\
\hline 3 & Mini-micro hydro & & \\
\hline 4 & Biomass & $4.8 \mathrm{kWh} / \mathrm{m}^{2} / \mathrm{day}$ & \\
\hline 5 & Solar Energy & $970 \mathrm{MW}$ & \\
\hline 6 & Wind Power & $1,995.2 \mathrm{MW}$ & $\begin{array}{c}\text { Practical } \\
\text { Potency }\end{array}$ \\
\hline 7 & Wave Power & $41,012 \mathrm{MW}$ & \\
\hline 8 & OTEC & $4,800 \mathrm{MW}$ & \\
\hline 9 & Tidal & & \\
\hline
\end{tabular}

\section{B. History of FiT in Indonesia}

In order to enhance renewable energy utilization, Indonesia has been implementing FiT since 2009. As a note, the Indonesia FiT is entirely different from that of other countries. The first FiT is designed for small scale hydropower. However, it is opened for other renewable energy resources. The equation to calculate the first FiT is divided for medium and low voltage. The electricity price at medium interconnected voltage is calculated by

$$
P(I D R / k W h)=656 \times F
$$

And at low interconnected voltage is

$$
P(I D R / k W h)=1,004 \times F
$$

Here $\mathrm{P}$ is price in Indonesia Rupiah (IDR) and $F$ is a factor depend on the location.

\section{B.1 FiT for Hydropower}


After the first one, the FiT for hydropower has been released two times. The second FiT for hydropower issued in the year 2014. Here the equation for medium and low interconnected voltage are calculated by the following equations.

$$
\begin{aligned}
& P(I D R / k W h)=1,075 \times F \\
& P(I D R / k W h)=1,270 \times F
\end{aligned}
$$

Here $\mathrm{P}$ is price in Indonesia Rupiah (IDR/kWh) and $F$ is a factor depend on the location. The reasons for changing the selling price are inflations and currency rates. As a note, the mechanical-electrical equipment is mainly imported and calculated in USD.

In order to accommodate the fluctuation of currency rate, the FiT for hydropower is changing into USD since 2015. The new FiT also depend on the type of small hydropower. It is divided into Run off River (RoR) type and Dam type. It also depends on the year. The new FiT for hydropower are shown in Table 2. The price shown in the table must mu multiple by location factor of $F$. The table shows that the purchase agreement is up to 20 years and the price during the contract is not fixed.

TABLE II. FIT FOR SMALL SCALE HYDROPOWER

\begin{tabular}{|l|l|c|c|}
\hline Type & $\begin{array}{l}\text { Interconnec } \\
\text { ted Voltage }\end{array}$ & Year 1 to 8 & Year 9 to 20 \\
\hline \multirow{2}{*}{ RoR } & Medium & $14.4 \mathrm{USD}$ Cent $/ \mathrm{kWh}$ & $9.0 \mathrm{USD}$ Cent $/ \mathrm{kWh}$ \\
\cline { 2 - 4 } & Low & $12.0 \mathrm{USD}$ Cent $/ \mathrm{kWh}$ & $7.5 \mathrm{USD}$ Cent $/ \mathrm{kWh}$ \\
\hline \multirow{2}{*}{$\begin{array}{l}\text { DA } \\
\text { M }\end{array}$} & Medium & $13.0 \mathrm{USD}$ Cent $/ \mathrm{kWh}$ & $8.1 \mathrm{USD} \mathrm{Cent} / \mathrm{kWh}$ \\
\cline { 2 - 5 } & Low & $10.8 \mathrm{USD}$ Cent $/ \mathrm{kWh}$ & $6.75 \mathrm{USD}$ Cent $/ \mathrm{kWh}$ \\
\hline
\end{tabular}

\section{B.2 FiT for Geothermal}

The first FiT designed for Geothermal in Indonesia was released in the year 2011. Here, the selling price was not calculated in IDR such as FiT for mini hydropower. The price was calculated in USD. The maximum selling price of Geothermal in the first FiT was 9.7 Cent USD/kWh. Here it is not divided into interconnected voltage. This FiT only used for one year. In the year 2012, the new FiT for Geothermal is released. The FiT is divided into high and medium interconnected voltage. The price for high and medium interconnected voltages were $10-17$ Cent USD/kWh and 11.5 - 18.5 Cent USD/kWh, respectively. This FiT only used for two years. In the year 2014, the previous FiT was revised. In the latest FiT, the price varies from 11.8 to 29.6 Cent USD/kWh. The variation depends on the Commercial Operation Date (COD). The new FiT of Geothermal is shown in Table 3.

TABLE III. FIT FOR GEOTHERMAL (CENT USD/KWH)

\begin{tabular}{|c|c|c|c|}
\hline COD & Region I & Region II & Region III \\
\hline 2015 & 11.8 & 17.0 & 25.4 \\
\hline 2016 & 12.2 & 17.6 & 25.8 \\
\hline 2017 & 12.6 & 18.2 & 26.2 \\
\hline 2018 & 13.0 & 18.8 & 26.6 \\
\hline
\end{tabular}

\begin{tabular}{|c|c|c|c|}
\hline COD & Region I & Region II & Region III \\
\hline 2019 & 13.4 & 19.4 & 27.0 \\
\hline 2020 & 13.8 & 20.0 & 27.4 \\
\hline 2021 & 14.2 & 20.6 & 27.8 \\
\hline 2022 & 14.6 & 21.3 & 28.3 \\
\hline 2023 & 15.0 & 21.9 & 28.7 \\
\hline 2024 & 15.5 & 22.6 & 29.2 \\
\hline 2025 & 15.9 & 23.3 & 29.6 \\
\hline
\end{tabular}

\section{B.3 FiT for Biomass and Biogas}

In the first development the FiT for Biomass and Biogas powerplant was the same. The first FiT for both resources were released in year 2012. The price at medium and low interconnected voltage are calculated by equation (5) and equation (6), respectively.

$$
\begin{aligned}
& P(I D R / k W h)=975 \times F \\
& P(I D R / k W h)=1,325 \times F
\end{aligned}
$$

In this equation, $F$ is location factor. This FiT was used only for two years. In 2014, the revised FiTs were released and the price divided into Biomass and Biogas. For the Biomass, the price for the medium and low interconnected voltage are calculated by equation (7) and equation (8), respectively.

$$
\begin{aligned}
& P(I D R / k W h)=1,150 \times F \\
& P(I D R / k W h)=1,500 \times F
\end{aligned}
$$

On the other hand, for the Biogas, the price for the medium and low interconnected voltage are calculated by equation (9) and equation (10), respectively.

$$
\begin{aligned}
& P(I D R / k W h)=1,050 \times F \\
& P(I D R / k W h)=1,400 \times F
\end{aligned}
$$

\begin{tabular}{|c|c|c|}
\hline Resource & $\begin{array}{c}\text { Interconnecte } \\
d \text { Voltage }\end{array}$ & Price (Cent USD/kWh) \\
\hline \multirow{3}{*}{ Biomass } & High & $11.48 \times F$ \\
\hline & Medium & $13.5 \times F$ \\
\hline & Low & $16.0 \times F$ \\
\hline \multirow{3}{*}{ Biogas } & High & $9.05 \times F$ \\
\hline & Medium & $10.64 \times F$ \\
\hline & Low & $13.14 \times F$ \\
\hline
\end{tabular}

In order to take the currency rate into account, the FiT for Biomass and Biogas has been released since 2016. The new FiT are shown in Table 4.

TABLE IV. FIT FOR BIOMASS AND BIOGAS

\section{B.4 FiT for Solar}


The first FiT of solar energy was released in 2013. Similar with Geothermal the FiT for solar power was calculated in USD since the beginning. In the first FiT the electricity price varied from 25 Cent USD/kWh to 30 Cent USD/kWh. The price was affected by local content of the solar cell. This FiT only used for 3 years. In 2016, the new FiT for Solar energy has been released. The selling price varied from 14.5 Cent USD/kWh to $25 \mathrm{USD} / \mathrm{kWh}$.

\section{B.5 Other resources}

Up to now, no FiT has been released for Wind Power, OTEC, Wave and Tidal Power. In particular for Wind Power, several Wind IPP projects have signed Power Purchase Agreement (PPA). However, the selling price was not calculated based on FiT. The price was calculated based on the Business to Business scheme.

\section{CONCLUSION}

The Feed-in tariff policy development in Indonesia has been overviewed. The results show that FiT development is very dynamic. It changes rapidly, even change in the same year. Mostly the FiT persists only for two years. In the beginning, the FiT for hydropower, Biomass, and Biogas were calculated in IDR currency. However, the recent FiTs are calculated in USD. On the other hand, the FiTs for Geothermal and Solar Energy are calculated based on USD currency since the beginning. The main conclusion can be drawn here is that the FiT system Indonesia need to be designed carefully. The FIT has no significant effect yet to the growth of the IPP. Thus, other supporting financial mechanisms must be provided by the GoI.

\section{References}

[1] T. Supriyasilp, M. Pinitjitsamut, K. Pongput, A. Waneset, S. Boonyanupong, S. Rakthai and T. Boonyasirikul, "A challenge of incentive for small hydropower commercial investment in Thailand", Renewable Energy 111, 2017, pp. 861-869.

[2] M. T. Garcia-Alvarez and R. M. Mariz-Perez, "Analysis of the succes of feed-in tariff for renewable energy promotion mechanism in the EU: lessons learn from Germany and Spain", Procedia-Social and Behaviour Sciences 65, 2012, pp.52-57.

[3] S. Tongsopit and C. Greacen, "An assessment of Thailand's feed-in tariff program”, Renewable Energy 60, 2013, pp.439-445.

[4] S. C. Chua, T. H. Oh, W. W. Goh, "Feed-in tariff outlook in Malaysia", Renewable and Sustainable Energy Reviews 15, 2011, pp. 705-712.

[5] B. Koo, "Examining the impacts of Feed-in tariff and the clean development mechanism on the Korea's renewable energy projects through comparative investment analysis”, Energy Policy 104, 2017, pp. 144-154.

[6] L. Poruschi, C. L. Ambrey and J.C.R. Smart,'Revisting feed-in tariffts in Australia: A review", Renewable and Sustainable Energy Reviews 82, 2018, pp. 260-270.

[7] X-L. Lim, W-H. Lam and R. Hashim,"Feasibility of marine renewable energy to the Feed-in Tariff system in Malaysia", Renewable and Sustainable Energy Reviews 49, 2015, pp. 708-719.

[8] M. del P. Pablo-Romero, A. Sanchez-Braza, J. Salvador-Ponce, N. Sanchez-Labrador,"An overview of feed-in tariffs, premiums and tenders to promote electricity from biogas in the UE-28", Renewable and Sustainable Energy Reviews 73, 2017, pp. 1366-1379.

[9] M.S. Umar, P. Jennings and T. Urmee,"Generating renewable energy from oil palm biomass in Malaysia: The Feed-in Tariff policy framework", Biomass and Bioenergy 62, 2014, pp. 37-46.

[10] B. Bakhtyar, K. Sopian, A. Zaharim, E. Salleh and C.H. Lim,’Potential and challenges in implementing feed-in tariff policy in Indonesia and the Philippines", Energy Policy 60, 2013, pp. 418-423.

[11] BPPT, "Indonesia Energy Outlook", 2016, Jakarta, Indonesia

[12] Kuncoro, Arif, Heru, "Renewable Energy for Power Generation in Indonesia", Ministry of Energy and Mineral Resource of Indonesia, Tokyo, 2011, p.8. 